\title{
LOUVAIN NATURAL RADIOCARBON MEASUREMENTS VIII
}

\section{E. GILOT}

Department of Nuclear Chemistry, University of Louvain,

Louvain, Belgium

The measurements reported in this list were made in the Louvain $\mathrm{C}^{14}$ Dating Laboratory in 1968 with the $0.6 \mathrm{~L} \mathrm{CH}_{4}$ proportional counter. The counter generally operates at $3 \mathrm{~atm}$ pressure. Samples too poor to provide $2 \mathrm{~L}$ methane are measured at $1000 \mathrm{~mm} \mathrm{Hg}$ pressure. Ages are calculated on the basis of a $\mathrm{C}^{14}$ half life of $5570 \mathrm{yr}$ and are quoted with $1 \sigma$ counting error. The description of each sample is based on information provided by the submitters.

Sincere thanks are due Prof. P. Capron for his constant guidance. Chemical preparation was done by Mr. F. Frix and maintenance of electronics by Mr. G. Michotte de Welle. Thanks are also due Dr. J. Mayaudon for the determination of organic nitrogen content in the bone samples. Financial support is provided by the Institut Interuniversitaire des Sciences Nucléaires, Brussels.

\section{SAMPLE DESCRIPTIONS}

\section{Anlier III series}

\section{GEOLOGIC SAMPLES}

Peat with alder rootlets $(A \ln u s)$, id. by J. Heim from Bois le Prêtre $\left(49^{\circ} 45^{\prime} 25^{\prime \prime} \mathrm{N}\right.$ Lat, $5^{\circ} 36^{\prime} 55^{\prime \prime} \mathrm{E}$ Long) in forest of Anlier at Habay la Neuve, Prov. of Luxembourg, Belgium, alt $430 \mathrm{~m}$. Bottom of Sub-Atlantic peat bog. Coll. 1963, subm. and pollen anal. by J. Heim, Univ. of Louvain, Lab. of Palynology.

\section{Lv-169. Anlier III/1}

$2060 \pm 75$ 110 B.c.

Peat from 70 to $80 \mathrm{~cm}$. Pollen analysis shows beginning of SubAtlantic period, with beginning of continuous curve of Fagus, end of continuous curve of Tilia and sporadic presence of corn pollen. Level assumed first Fagus maximum F I masked by predominance of Alnus. In this region, date of this maximum is presumed A.D. 100 (Mullenders et al., 1967).

\section{Lv-170. Anlier III $/ 2$}

$$
1600 \pm 90
$$

Peat from 80 to $90 \mathrm{~cm}$. Age too young according to Lv-169. Sample probably contaminated by alder rootlets.

\section{Anlier IV series}

Peat with alder rootlets (Alnus), id. by J. Heim from Gros Chêne $\left(49^{\circ} 45^{\prime} 55^{\prime \prime} \mathrm{N}\right.$ Lat, $5^{\circ} 39^{\prime} 20^{\prime \prime}$ E Long) at Habay la Neuve, Prov. of Luxemburg, Belgium, alt $460 \mathrm{~m}$. Bottom of Sub-Atlantic peat bog in moist depression of forest of Anlier. Coll. 1963, subm. and pollen anal. by J. Heim. 
Peat from 50 to $60 \mathrm{~cm}$. Sample probably contemporaneous of $3 \mathrm{rd}$ Fagus maximum F III age estimated A.D. 1200 (Mullenders et al., 1967), although maximum does not appear in pollen diagram because of predominance of Salix and Alnus.

\section{Lv-172. Anlier IV/2}

$1490 \pm 105$

Peat from 60 to $70 \mathrm{~cm}$. According to pollen curves of Tilia, Carpinus, and corn, level younger than Lv-169 and perhaps corresponding to 2nd Fagus maximum F II age estimated A.D. 600 (Mullenders et al., 1967).

\section{ARCHAEOLOGIC SAMPLES}

\section{Lv-374. Cornaux, Switzerland}

$2410 \pm 120$

Wood (Quercus), id. by A. Munaut from Cornaux $\left(47^{\circ} 02^{\prime} \mathrm{N}\right.$ Lat, $7^{\circ} 04^{\prime}$ E Long), Canton of Neuchâtel, Switzerland. Remains of wooden bridge found in former bed of Thiele R. at $2 \mathrm{~m}$ below Roman horizon. Coll. 1965 and subm. by J. P. Jecquier, Cantonal Archaeol. Mus. of Neuchâtel. Among remains of bridge, 4 skeletons of warrior and horse bones, a Late La Tene sword, and 3 heads of pike. Bridge assumed Celtic (Schwab, 1966).

\section{Lv-393. Elkab, Egypt}

$8350 \pm 160$

Charcoal from Elkab $\left(25^{\circ} 08^{\prime} \mathrm{N}\right.$ Lat, $32^{\circ} 47^{\prime} \mathrm{E}$ Long), Prov. of Edfu, Egypt. Sample imbedded at $1 \mathrm{~m}$ depth in clayey silt filling former bed probably of Nile R. and assoc. with lamellar microlithic epipaleolithic industry. Coll. 1968 and subm. by P. Vermeersch, Comité des Fouilles Belges en Egypte. Comment (P.V.): this industry is still unknown in Egypt. It completes hiatus between Upper Sebilian (9000 B.c.) and Fayum (4600 B.c.) in chronology of prehistoric industries $\mathbf{N}$ of Assawan (Vermeersch, 1969). Sample too small to suffer $\mathrm{NaOH}$ leach.

\section{Lv-383. Grotte Blanchard, France}

$$
\begin{gathered}
11,280 \pm 220 \\
9330 \text { в.c. }
\end{gathered}
$$

Burned bones from cave hearth in Grotte Blanchard in Magdalenian site of La Garenne at Saint Marcel ( $46^{\circ} 34^{\prime} \mathrm{N}$ Lat, $1^{\circ} 30^{\prime} \mathrm{E}$ Long), Dept. of Indre, France. Sample from upper part of Level 2 (Allain, 1953; 1961) near bottom of cave. Coll. 1958 by M. R. Sauter; subm. by A. LeroiGourhan, Mus. de l'Homme, Paris. Cave is separated from upper cave "Grand Abri" and closed by rock fall and clay layer containing Upper Magdalenian industry from Level 4 and 7 bis. Hearth from this Level 4, in "Grand Abri," is dated by Libby as follows: C-577, burned bone, 9159 в.C. \pm 480 ; C-578, ashy material, 13,897 в.C. \pm 1200 ; C-579, burned bone from same horizon but outside hearth, 11,036 в.c. \pm 560 (Libby, 1955). Level 6 is dated as L-399 D, burned bone from hearth, 7550 B.c. \pm 500 (Radiocarbon, 1959, v. 1, p. 23), and as Gsy-34, charcoal cinders 
and charred bones, 9280 B.c. \pm 500 (Radiocarbon, 1966, v. 8, p. 134). Present $\mathrm{C}^{14}$ date is a little more recent than assumed by Allain. Comment: sample was dissolved in $\mathrm{HCl}$ and solid residue used for dating.

Lv-358. El Khiam, Jordan

$2990 \pm 250$

Bones from El Khiam (31 $37^{\prime} 50^{\prime \prime} \mathrm{N}$ Lat, $35^{\circ} 16^{\prime} 00^{\prime \prime} \mathrm{E}$ Long), Jordan. Sample from Area II B, Level $1 \mathrm{~b}$ at $0.40 \mathrm{~m}$ depth, Prepottery Neolithic horizon, Tahounian facies (Echegaray, 1963; 1964). Coll. 1962 and subm. by J. G. Echegaray, Prehist. Mus. of Santander, Spain. Comment (J.G.E.): sample dissolved in $\mathrm{HCl}$ and solid residue used for dating; measured at $1000 \mathrm{~mm} \mathrm{Hg}$ pressure. In other sites, this horizon is dated ca. 6000 в.c.

\section{Ordona series, Italy}

Samples from Ordona $\left(41^{\circ} 18^{\prime} \mathrm{N}\right.$ Lat, $15^{\circ} 37^{\prime} \mathrm{E}$ Long), Prov. of Foggia, Italy. Series dates occupation of ancient Roman colony at Herdoniae (Mertens, 1967). Other dates pub. in Radiocarbon, 1965, v. 7 and 1967, v. 9. Subm. by J. Mertens, Univ. of Louvain, Archaeol. Inst.

\section{Lv-282. Ordona 65.0R.76}

$2160 \pm 260$

Charcoal from pit dug in rock and filled up before building of Temple B. Coll. 1965 by J. Mertens. Temple is archaeologically dated 2nd century в.c. $\mathrm{C}^{14}$ date agrees with archaeology. Comment: sample measured at $1000 \mathrm{~mm} \mathrm{Hg}$ pressure.

\section{Lv-294. Ordona 65.0R.92}

$1820 \pm 80$

Charcoal found at $1.20 \mathrm{~m}$ depth with potsherds in filling cryptoporticus of Forum. Coll. 1965 by G. De Boe. Archaeologic estimation is 2 nd half of 1st century A.D.

\section{Lv-295. Ordona 66.0R.01}

$1900 \pm 85$

Charcoal from incineration grave at $1.10 \mathrm{~m}$ depth in zone of Amphitheatre. Coll. 1966 by R. Iker. In grave, coin of emperor Domitian (85 to 96 A.D.)

\section{Alba Fucens series, Italy}

Charcoal from Alba Fucens ( $42^{\circ} 05^{\prime} \mathrm{N}$ Lat, $13^{\circ} 25^{\prime} \mathrm{E}$ Long), Prov. of Aquila, Italy. Coll. 1966 by G. De Boe; subm. by J. Mertens.

\section{Lv-334. Alba Fucens 66.AF.18}

$2350 \pm 75$

Burned horizon in shop along principal street of town.

Lv-336. Alba Fucens 66.AF.30

$1700 \pm 75$

Burned horizon from urban villa. Trench 66.IV. Coins found in same horizon are dated from 3rd and 4th centuries A.D. 


\section{Lv-337. Alba Fucens 66.AF.36}

Burned horizon, mixed, in back of room of urban villa. Trench 66.IV, S of Wall B.

\section{Lv-338. Alba Fucens 66.AF.46}

$1440 \pm 70$ 66.III.

Burned horizon from room of important house of town. Trench

General Comment: archaeologic context for these samples indicates Late Roman epoch and layers seem homogenous. Two late $\mathrm{C}^{14}$ dates agree with interpretation but 2 ancient are still unexplained. New investigations are necessary.

\section{Lv-333. Bruges}

A.D. 1090

$860 \pm 95$

Wood from pile used to lay out plan of Roman St. Donatius church at Bruges $\left(51^{\circ} 13^{\prime} \mathrm{N}\right.$ Lat, $3^{\circ} 13^{\prime} \mathrm{E}$ Long), Prov. of West Flanders, Belgium. Sample found at $4 \mathrm{~m}$ depth. Coll. 1955 and subm. by J. Mertens. Church is generally dated as beginning of 10 th century. Dates agrees with $\mathrm{C}^{14}$ date for basement of pre-Roman construction: Lv-43, A.D. $1110 \pm 130$ (Radiocarbon, 1962, v. 4, p. 97 and 1964, v. 6, p. 160).

\section{Lv-349. Liege}

$880 \pm 240$

Wood (Quercus) from statue from private collection of M. Van Zuylen, Quai Van Beneden, Liege $\left(50^{\circ} 40^{\prime} \mathrm{N}\right.$ Lat, $5^{\circ} 42^{\prime} \mathrm{E}$ Long), Belgium. Coll. 1967 and subm. by R. Antoine, Univ. of Louvain. Statue is archaeologically estimated from 14 th century. $\mathrm{C}^{14}$ date confirms expectation. Comment: sample measured at $1000 \mathrm{~mm} \mathrm{Hg}$ pressure.

\section{Lv-317. Hal}

$2000 \pm 85$

Charcoal from prehistoric hearth at Maasdaal $\left(50^{\circ} 42^{\prime} 16^{\prime \prime} \mathrm{N}\right.$ Lat, $4^{\circ} 15^{\prime} 16^{\prime \prime}$ E Long) near Hal, Prov. of Brabant, Belgium. Hearth is overlain by $1.30 \mathrm{~m}$ dark sandy clay and yellowish sand. Coll. 1966 and subm. by R. Borremans, Zuidwest-Brabants Heemskundig Mus. Site is situated within short distance of spring on $\mathrm{E}$ bank of Senne R. Only artifact found in hearth is potsherd dated as La Tene (without precision). Other potsherds of same epoch were found in neighborhood. $\mathrm{C}^{14}$ date confirms estimation.

Date lists:

Gif-sur-Yvette I

Lamont $\mathrm{V}$

Louvain I

Louvain II

Louvain III

Louvain V

\section{REFERENCES}

Coursaget and Le Run, 1966

Olson and Broecker, 1959

Dossin, Deumer, and Capron, 1962

Deumer, Gilot, and Capron, 1964

Gilot, Ancion, and Capron, 1965

Gilot, 1967

Allain, J., 1953, Foyers et Dallages dans le Magdalénien de la Garenne à St. Marcel (Indre): L'Anthropologie, no. 34, p. 284-294. 
Allain, J., 1961, Premier aperçu d'ensemble sur l'industrie magdalénienne de la Garenne: Soc. Préhistorique Française Bull., v. LVIII, nos. 8, 9, 10, p. 594-604.

Coursaget, J. and Le Run, J., 1966, Gif-sur-Yvette natural radiocarbon measurements I: Radiocarbon, v. 8, p. 128-141.

Deumer, J. M., Gilot, E., and Capron, P. C., 1964, Louvain natural radiocarbon measurements II: Radiocarbon, v. 6, p. 160-166.

Dossin, J. M., Deumer, J. M., and Capron, P. C., 1962, Louvain natural radiocarbon measurements I: Radiocarbon, v. 4, p. 95-99.

Echegaray, J. G., 1963, Nouvelles fouilles à El Khiam: Biblique Rev., v. LXX, p. 94-119. 1964, 1966: Excavaciones en la Terraza de El Khiam (Jordania): Bibliotheca Praehistorica Hispana, v. V, 2 tomes.

Gilot, E., 1967, Louvain natural radiocarbon measurements V: Radiocarbon, v. 9, p. 295-300.

Gilot, E., Ancion, N., and Capron, P. C., 1965, Louvain natural radiocarbon measurements III: Radiocarbon v. 7, p. 118-122.

Libby, W. F., 1955, Radiocarbon dating, 2nd ed.: Chicago, Univ. Chicago Press, p. 85-86.

Mertens, J., 1967, Ordona II Rapport provisoire sur les travaux de la mission belge en 1964/65 et 1965/66: Etudes de Philologie, d'Archéologie et d'Histoire anciennes, v. IX, $181 \mathrm{p}$.

Mullenders, W., Gilot, E., Ancion, N., and Capron, P. C., 1967, Evolution of the vegetation in High Belgium and its radiocarbon chronology, in: Cushing, E. J. and Wright, H. E., Jr., eds., Quaternary Paleoecology, New Haven, Yale Univ. Press, p. 333-339.

Olson, E. A. and Broecker, W. S., 1959, Lamont natural radiocarbon measurements V: Am. Jour. Sci. Radiocarbon Supp., v. 1, p. 1-28.

Schwab, H., 1966, Keltische Brücke zwischen Cornaux (NE) and Gals (BE): UrSchweiz-La Suisse primitive, v. 30, no. 1, p. 9-11.

Vermeersch, P., 1969, Les fouilles d'Elkab: Deutschen Morgenländischen Gesell. Zeitschr., Supp. no. 1, XVII Deutscher Orientalistentag vorträge, t. I, p. 32-36. 